\title{
Is Magnesium Required for Optimal Level of Serum Vitamin D? A Hospital-based Study
}

\author{
SK Rai', Barun K Chakrabarty², Mukul Bajpai ${ }^{3}$, Vimal Upreti ${ }^{4}$
}

\begin{abstract}
Objective: Magnesium (Mg) plays a crucial role in vitamin D synthesis and metabolism. In magnesium-dependent vitamin-D-resistant rickets supplementation of this micronutrient changed the resistance to vitamin D treatment significantly. This study aims to evaluate the correlation between serum $\mathrm{Mg}$ and vitamin $\mathrm{D}$ total levels in an otherwise healthy individual. We hypothesized that in hypovitaminosis $\mathrm{D}$, there is also a Hypomagnesaemia as well.
\end{abstract}

Materials and methods: The study population comprises of 252 young patients, aged between 18 years and 45 years, consisting of individuals with and without hypovitaminosis D. The correlation between measured serum 25 hydroxyvitamin D total $(25(\mathrm{OH}) \mathrm{D}) \mathrm{magnesium}$ and calcium level concentrations were studied.

Results: The mean age of the studied population was $31.5 \pm 2.32$ years, and studied groups, i.e. those with hypovitaminosis $D$ and those without it were age matched. The mean $25 \mathrm{OH}$ Vitamin D Total, Ca, and Mg level in the total study population was $20.32 \pm 6.84 \mathrm{ng} / \mathrm{mL}, 9.6 \pm 0.52 \mathrm{mg} / \mathrm{dL}$, $2.24 \pm 0.22 \mathrm{mg} / \mathrm{dL}$, respectively. The mean serum $25(\mathrm{OH}) \mathrm{D}$ level was $23.62 \pm 2.12$ in vitamin $\mathrm{D}$ insufficient group; however, it was $14.84 \pm 2.74$ in vitamin D deficient cases. The mean serum Mg level was $2.27 \pm 0.18 \mathrm{mg} / \mathrm{dL}$ in the vitamin $\mathrm{D}$ insufficient group, and it was $2.23 \pm 0.25$ in the vitamin $\mathrm{D}$ deficient group.

Conclusion: In our study, we have demonstrated that there is no statistically significant associations exist between measured serum Mg and $25(\mathrm{OH})$ total vitamin D levels. Level of vitamin D and serum $\mathrm{Mg}$ is independent of each other and taking vit $\mathrm{D}$ alone is sufficient enough to combat hypovitaminosis D. However, further large longitudinal studies are desirable to evaluate the causal mechanisms and the clinical connotation of the current findings.

Keywords: Hypovitaminosis D, Magnesium, Vitamin D.

Indian Journal of Medical Biochemistry (2019): 10.5005/jp-journals-10054-0098

\section{INTRODUCTION}

We all know and it is well documented also that vitamin $D$ is a group of lipid or fat-soluble secosteroid vitamin, and it is essential for various crucial cell functions and metabolism. It is associated with bone mineralization by maintaining serum calcium and phosphorus concentrations at required levels. It has an important role in cellular differentiation and replication in many organs, and glucose homeostasis as well. Many studies showed that an adequate intake of this vitamin could prevent the potential risk of development of skeletal and non-skeletal disorders such as atopic conditions, few types of neoplasm, autoimmunity, chronic hepatitis $C$ and cardiometabolic diseases. ${ }^{1-5}$ It is now proven beyond doubt that the blood levels of vitamin D during childhood can prevent many diseases which are just mentioned in adulthood. ${ }^{6,7}$

Vitamin D is synthesized de novo in the skin dependent on sun exposure which is the major natural source; however, it is welldocumented from many studies that the vitamin D deficiency is prevalent worldwide even in sunny countries like India.

Vitamin D plays a significant role in calcium and phosphate homeostasis and metabolism. It is also an important micronutrient for bone health. ${ }^{8}$ After the discovery of the universal presence of vitamin $D$ receptors and enzyme in most organs of the body, studies have been provided wider insight about the pleiotropic non-skeletal roles for this steroid hormone. The widespread occurrence of vitamin D deficiency, ${ }^{9}$ even in the countries where there is abundant of sunlight, along with several perceived vitamin D supplementation benefits and improved accessibility of vitamin D assessment amenities has propelled the demand of screening for the vitamin D status. ${ }^{10}$
${ }^{1}$ Orthopaedician, ${ }^{2}$ Clinical Specialist (Pathology), ${ }^{3}$ Clinical Specialist (Pathology and Microbiology), ${ }^{4}$ Endocrinologist

${ }^{1}$ Department of Orthopaedics, Base Hospital, Guwahati, Assam, India

2,3 Department of Pathology, Base Hospital, Guwahati, Assam, India

${ }^{4}$ Department of Medicine, Base Hospital, Guwahati, Assam, India

Corresponding Author: SK Rai, Orthopaedician, Department of Orthopaedics, Base Hospital, Guwahati, Assam, India, e-mail: skrai47@ yahoo.com

How to cite this article: Rai SK, Chakrabarty BK, Bajpai M, Upreti V. Is Magnesium Required for Optimal Level of Serum Vitamin D?: A Hospital-based Study. Indian J Med Biochem 2019;23(2):254-258.

Source of support: Nil

Conflict of interest: None

Many factors like lack of adequate sun exposure, low dietary intake, physical activity, air pollution, and the season can be an important factor for hypovitaminosis D. However, the effects of some more essential elements like magnesium shall be taken into account in this regard as many authors reported. ${ }^{11-15}$

Hypomagnesemia is possibly the most undervalued and underdiagnosed electrolyte abnormalities in current medical practice, and its role in Vit D hemostasis is yet to be understood. Magnesium (Mg) is the second most available intracellular cation after potassium and exert a key role in mineralization of bone. It is also vital for the synthesis and metabolism of vitamin D as well. ${ }^{16,17}$

Studies have observed that insufficient vitamin $D$ status is still prevalent in the US despite food fortification program and use

(O) The Author(s). 2019 Open Access This article is distributed under the terms of the Creative Commons Attribution 4.0 International License (https://creativecommons. org/licenses/by-nc/4.0/), which permits unrestricted use, distribution, and non-commercial reproduction in any medium, provided you give appropriate credit to the original author(s) and the source, provide a link to the Creative Commons license, and indicate if changes were made. The Creative Commons Public Domain Dedication waiver (http://creativecommons.org/publicdomain/zero/1.0/) applies to the data made available in this article, unless otherwise stated. 
of dietary supplementation, and a significant proportion of the interpersonal variation in serum 25 -hydroxyvitamin $D(25(\mathrm{OH}) \mathrm{D})$ levels is unexplained. ${ }^{18}$

In contrary to calcium, magnesium is an "unheard and orphan nutrient" that has been noticeably understudied as it does not invite any direct impact. Low dietary intake and deficiency of magnesium have been associated with atherosclerotic vascular disease, migraine headache, bronchial asthma, type 2 diabetes, osteoporosis, metabolic syndrome, hypertension, sudden cardiac death, and colon cancer. A study done by Robert Whang et al. in $2005-2006^{19}$ based on surveys conducted showed that the dietary intake of magnesium of $48 \%$ of the United States population was less than the recommended amount and the statistical figure was down from $56 \%$ from earlier surveys in 2001-2002. He also noted that amongst the adults and elderly population of the United States there is a tendency of raising calcium-to-magnesium food-intake ratios, excluding supplemental intakes, which indulge calcium over magnesium.

The aim of the present study is to assess the relationship between evaluated serum $\mathrm{Mg}$ and $25 \mathrm{OH}$ vitamin D total levels, as hypovitaminosis $\mathrm{D}$ is prevalent in our country.

\section{Materials AND METHOdS}

Total 252 young, otherwise healthy patients, aged between 18 years and 45 years who attended orthopedics OPD of a tertiary care hospital in Guwahati, Assam, India between Aug 2017 and Dec 2017 were included in the study. The study has been cleared by the Institutional Ethical Committee of the hospital and informed consent was taken from the participants.

\section{Inclusion Criteria}

- Age 18-45 years

- Individuals not taking any vitamin D and calcium supplements

- Individuals not taking any multivitamins calcium supplements

- Individuals do not have any lifestyle modifying disease like obesity, diabetes, hypertension or any endocrinological disorder

- Individuals who were a nonsmoker and not habitual drinkers

\section{Exclusion Criteria}

- Individuals taking vitamin D and calcium supplements

- Individuals taking any Multivitamins calcium supplements

- Persons with a history of recent fracture

- Individuals who were presented with a history of taking medication for hypertension, NIDDM, endocrinological disorder, chronic hepatic disorder, chronic renal disease, chronic heart failure, etc.

After an explanation of the study objectives and protocols to each patient, written informed consent and oral assent were obtained. The study population was randomly selected from individuals attending orthopedics outpatient department (OPD).

Morning fasting serum samples were collected in the plastic tube with separation gel and processed within a maximum of 08 hours after placing it at $18-25^{\circ} \mathrm{C} .25(\mathrm{OH})$ vitamin $D$ total serum concentration was evaluated by an enzyme immunoassay method with a final fluorescent detection technique (ELFA technique) in a fully automated quantitative immune analyzer VIDAS instrument. The VIDAS $25 \mathrm{OH}$ vitamin D Total measurement range extends from $8.1 \mathrm{ng} / \mathrm{mL}$ up to $126.0 \mathrm{ng} / \mathrm{mL}$. Values below the lower limit of the measurement range were reported as $<8.1 \mathrm{ng} / \mathrm{mL}$. Values above the upper measurement range were reported as $>126.0 \mathrm{ng} / \mathrm{mL}$. The inter-assay coefficient of variation of the test was $20 \% .25(\mathrm{OH})$ vitamin D total level of below $20 \mathrm{ng} / \mathrm{mL}$ was considered as vitamin D deficiency, levels of 20 to $29 \mathrm{ng} / \mathrm{mL}$ were labeled as vitamin D insufficiency and level $>29$ was considered as vitamin D sufficient cases. Quantitative determination of magnesium in human serum was done by using modified methylthymol blue (MTB) complexometric method on the fully automated biochemistry analyzer Dimension ${ }^{\circledR}$ in vitro diagnostic clinical chemistry system. The analytical measurement range of the parameter was 0.0-20.0 $\mathrm{mg} / \mathrm{dL}$. Serum $\mathrm{Mg}$ level reference range was considered 1.8-2.4 $\mathrm{mg} / \mathrm{dl}$ as per kit literature. Proper quality control and calibration measures were ensured.

Data were analyzed by SPSS statistical software (version 20.0; SPSS Inc., Chicago, IL, USA). A p value $<0.05$ was considered significant for the analyzed parameters. The relationship between serum magnesium and vitamin D levels was assessed through linear regression analysis purposing $\mathrm{Mg}$ as an independent variable and $25(\mathrm{OH})$ vitamin D Total as a dependent variable. Mean Mg serum level in deficient and normal group was compared by t-test analysis.

\section{Results}

The study population consisted of 252 patients comprising three groups vitamin D deficient, vitamin D insufficient, and vitamin D sufficient population.

The mean age of study population was $31.5 \pm 2.32$ years and the study groups, i.e., those with hypovitaminosis $D$ and those without it were age-matched $(30.17 \pm 2.32$ vs. $28.23 \pm 2.66$ years, respectively, $p>0.05)$. Baseline descriptive features of the study participants are displayed in Table 1. The parameter level in different subgroups is shown in Table 2.

The mean value of $25 \mathrm{OH}$ vitamin D total, calcium, and magnesium level in the total study population were $20.32 \pm 6.84$ $\mathrm{ng} / \mathrm{mL}, 9.6 \pm 0.52 \mathrm{mg} / \mathrm{dL}, 2.24 \pm 0.22 \mathrm{mg} / \mathrm{dL}$, respectively as shown in Table 3. . According to t-test analysis, the mean serum magnesium level was $2.24 \pm 0.22 \mathrm{mg} / \mathrm{dL}$ in the studied group comprising vitamin $D$ deficient and insufficient cases which were not statistically significantly different from mean Mg level $(2.22 \pm 0.18 \mathrm{mg} / \mathrm{dL})$ in vitamin $D$ sufficient cases $(p=0.63)$. The t-test analysis also showed that the difference in mean serum Ca level amongst the two above mentioned group was not statistically significant $(p=0.4)$. The linear

Table 1: Baseline biochemistry of study populations

\begin{tabular}{lll}
\hline Parameters & Normal group & Deficient group \\
\hline Age & $28.23 \pm 2.66$ & $30.17 \pm 2.32$ \\
BMI & $19.58 \pm 4.56$ & $19.64 \pm 5.41$ \\
Systolic BP & $101.29 \pm 12.58$ & $102.78 \pm 13.25$ \\
Diastolic BP & $62.99 \pm 9.52$ & $71.37 \pm 9.87$ \\
Total cholesterol & $139.19 \pm 36.44$ & $149.89 \pm 30.97$ \\
LDL-cholesterol & $73.29 \pm 23.82$ & $79.81 \pm 34.78$ \\
HDL-cholesterol & $39.71 \pm 18.49$ & $49.34 \pm 11.34$ \\
AST & $22.51 \pm 9.78$ & $24.49 \pm 10.54$ \\
ALT & $17.21 \pm 19.10$ & $19.45 \pm 8.37$ \\
Fasting blood sugar & $83.98 \pm 15.34$ & $91.34 \pm 14.41$ \\
Postprandial sugar & $111.29 \pm 23.58$ & $116.78 \pm 13.22$ \\
TG & $94.46 \pm 41.88$ & $94.21 \pm 41.33$ \\
Uric acid & $5.23 \pm 2.19$ & $4.17 \pm 2.42$ \\
Hemoglobin & $9.31 \pm 3.22$ & $9.54 \pm 3.78$ \\
\hline
\end{tabular}


Is Magnesium Required for Optimal Level of Serum Vitamin D? A Hospital-based Study

Table 2 :Descriptive Statistics of Groups

\begin{tabular}{llll}
\hline & $\begin{array}{l}\text { Vit } \mathrm{D} \\
(\mathrm{ng} / \mathrm{mL}) \\
\text { Mean } \pm \mathrm{SD}\end{array}$ & $\begin{array}{l}\mathrm{Mg} \\
(\mathrm{mg} / \mathrm{dL}) \\
\text { Mean } \pm \mathrm{SD}\end{array}$ & $\begin{array}{l}\mathrm{Ca} \\
(\mathrm{mg} / \mathrm{dL}) \\
\text { Mean } \pm S D\end{array}$ \\
\hline $\begin{array}{l}\text { Vit D deficient } \\
\text { cases (vit } \mathrm{D}<20)\end{array}$ & $14.84 \pm 2.74$ & $2.23 \pm 0.25$ & $9.56 \pm 0.55$ \\
$(\mathrm{~N}=130)$ & & & \\
$\begin{array}{l}\text { Vit D insufficient } \\
\text { cases (vit D 20-29) } \\
(\mathrm{N}=88)\end{array}$ & $23.62 \pm 2.12$ & $2.27 \pm 0.18$ & $9.65 \pm 0.45$ \\
$\begin{array}{l}\text { Vit D sufficient } \\
\text { cases (Vit D }>29)\end{array}$ & $32.7 \pm 3.05$ & $2.22 \pm 0.18$ & $9.67 \pm 0.56$ \\
$(\mathrm{~N}=34)$ & & & \\
\hline
\end{tabular}

regression analysis exhibited that as one unit increase in $\mathrm{Mg}$ level, $25(\mathrm{OH}) \mathrm{D}$ level decreases -0.282 and one unit increase in Ca level raises $25(\mathrm{OH})$ D level by 0.665 , but the relationship is not statistically significant relationship ( $p=0.889$ and 0.425 , respectively).

\section{Discussion}

To the best of our knowledge, this study is the first of its kind in northeastern India which examined the association of serum $25(\mathrm{OH})$ vitamin D total levels with serum Mg in a nationally-representative economically productive sample of the young individual population. Recent studies revealed that deficiency of vitamin $D$ is vastly prevalent in Indian population being young, children and adolescents and shall be considered an unrecognized emerging pandemic public health problem in many parts of the world. ${ }^{20-22}$ Vitamin D is a group of secosteroids prohormone and lipid-soluble in chemical nature. Vitamin D deficiency is important because it is being utilized in many tissues due to key roles, especially in bone metabolism.

Studies revealed the skeletal and extraskeletal health effects of this vitamin. ${ }^{23}$ Recent studies have recognized associations between vitamin D insufficiency/deficiency and an increased risk of various nonosseous morbidities like cardiovascular diseases, diabetes, autoimmune diseases, allergies, asthma as well as various malignancies. ${ }^{24,25}$ Vitamin D testing has, therefore, become an important assay of general health evaluation status. Vitamin $D$ is found in two major natural forms known as vitamin D2

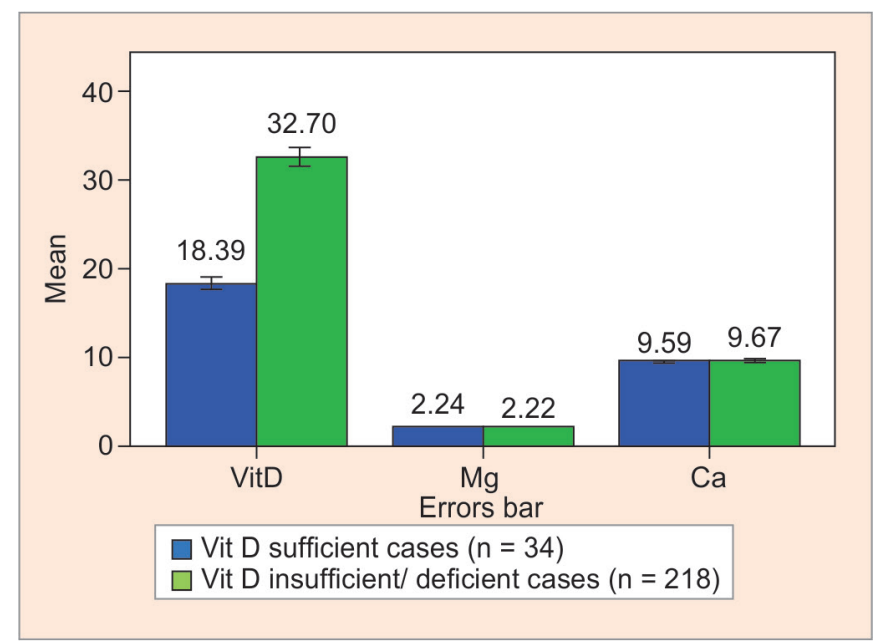

Graph 1: Comparison of $25 \mathrm{OH}$ vitamin D total, calcium and magnisium level
Table 3: Descriptive statistics of study population

\begin{tabular}{llll}
\hline & Vit $D$ & $M g$ & $C a$ \\
$n=252$ & Mean $\pm S D$ & Mean $\pm S D$ & Mean $\pm S D$ \\
\hline Mean & $20.32 \pm 6.84$ & $2.24 \pm 0.22$ & $9.6 \pm 0.52$ \\
Range & $(9.7-38.1) 28.4$ & $(1.9-3) 1.1$ & $(8.3-10.8) 2.5$ \\
\hline
\end{tabular}

(ergocalciferol) and vitamin D3 (cholecalciferol). Collectively they are known as calciferol. Endogenously Vitamin D3 is produced from 7-dehydrocholesterol on the skin by the effect of solar ultraviolet radiation. It is also present in various foods (eg. fatty fish). Vitamin D2 is available from exogenous source only. Negligible amounts of vitamin D2 are found in food like mushrooms, vegetables. Both vitamins D2 and D3 are therapeutically given as medical supplementation and are identically metabolized by the body. Within the human body, $25-(\mathrm{OH})$ vitamin $\mathrm{D}$ is the chief storage form of vitamin D. It is found in significant concentrations in serum or plasma, therefore to determine of nutritional status vitamin $\mathrm{D}$, $25-(\mathrm{OH})$ vitamin $\mathrm{D}$ is utilized as the preferred analyte in the clinical chemistry., In a triple masked clinical controlled trial among 50 obese 10-16 years aged children Kelishadi R et al., showed vitamin $D$ supplementation was effective in decreasing insulin resistance and risk factors for cardiometabolic diseases. ${ }^{25}$

Magnesium, as the second intracellular positive action may effect on this process. Magnesium homeostasis is retained by the complex interactions of the gastrointestinal tract, skeletal system, and kidneys. For vitamin D synthesis magnesium appear as a crucial cofactor and known to require for feed-forward loop to maintain its homeostasis. Deng et al. ${ }^{26}$ noticed the inter-relationship between body $\mathrm{Mg}$ and vitamin D status and showed that intake of $\mathrm{Mg}$ supplementation alone or along with vitamin D may improve in vitamin D status. Later on, Vojtková et al. found that deficient vitamin $D$ type 1 diabetic child has lower Mg level in their blood levels. ${ }^{27}$ They formulate that this may be the result of the central role in mineral homeostasis, regulating parathormone secretion and vitamin $\mathrm{D}$ action and activation. Subsequently, Sahota et al. ${ }^{28}$ found in diagnosed osteoporosis patients $\mathrm{Mg}$ is a crucial contributing factor along with vitamin $\mathrm{D}$ deficiency and reduced parathormone level. Comparison of evaluated serum $25 \mathrm{OH}$ vitamin D total, Calcium, and Magnesium level in all three groups has been shown in Graph 1. Calcium and Mg serum level comparison in Vit D deficient and sufficient cases are shown in Graph 2. Contrary to the above findings, our study

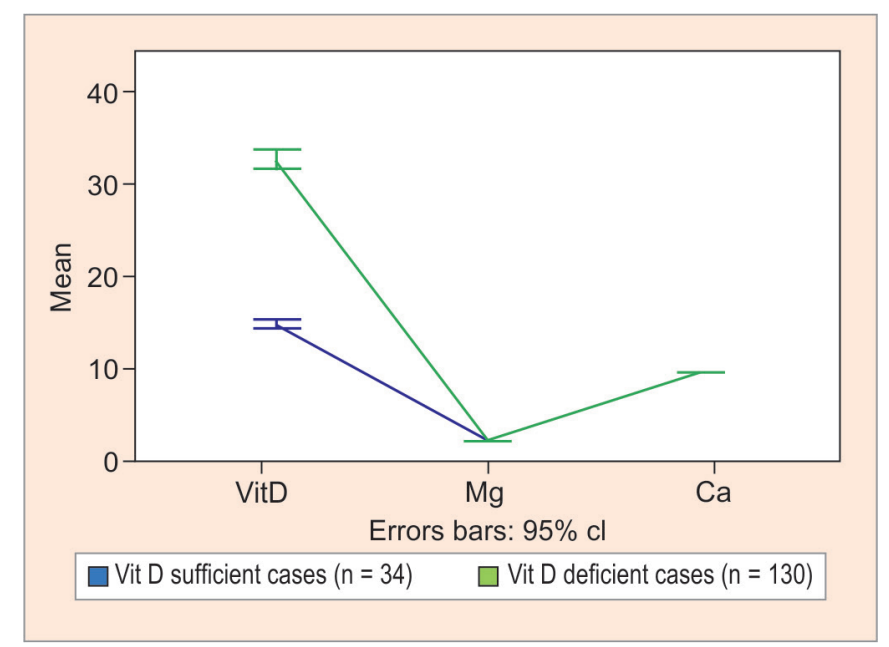

Graph 2: Diagram showing Ca and Mg level comparison in vit $\mathrm{D}$ deficient and sufficient cases 
did not show any statistically significant correlation between hypovitaminosis D and serum Magnesium level.

\section{STUDY LIMITATIONS AND STRENGTHS}

The main limitation of this study was its cross-sectional nature, therefore the associations of diverse variables should be considered with caution. The study is small, and further longitudinal large studies are required to find the underlying mechanisms and the clinical significance of this association. The ideal method for analyzing samples for Vitamin D level is liquid chromatography coupled to mass spectrometry method (LC-MS/MS). We have utilized most commonly used economical fully automated immune analyzer. The method has its inherent limitations related to interference with certain sera containing antibodies directed against reagent components. Around $40 \%$ of total body magnesium content is intracellular, and $60 \%$ of magnesium is present in the skeletal system, with less than $1 \%$ is present in extracellularuids. Only $0.3 \%$ of total body magnesium is found in serum; therefore, serum magnesium concentration may be a poor predictor of intracellular magnesium content.

The study strengths are its novelty in the younger economically productive age group and nationally representative study population, which would upsurge the importance and utilization of the study findings.

\section{Conclusion}

Our study revealed in the studied population there is no statistically significant association between measured serum $25 \mathrm{OH}$ vitamin D Total and serum magnesium levels. We further noticed that in hypovitaminosis $D$ is independent of the serum level of magnesium. Therefore, we proposed that hypovitaminosis $D$ is not associated with hypomagnesemia as observed by many author supra. However, further longitudinal studies are required to find the fundamental mechanisms and the clinical connotation of this association.

\section{Clinical significance}

The study got the potential to review the need for medicational cost and unwanted side effects due to multitherapy with vitamin D and magnesium based on serum magnesium level as per present clinical practice. It also highlighted the need to monitor body magnesium level with better parameter rather than serum magnesium level. Our study showed that the level of vitamin $D$ and serum magnesium is not dependent on each other and therefore multitherapy with magnesium and vitamin D supplementation is not recommended to combat hypovitaminosis $D$ based on serum magnesium level. Improved consideration of supplementation with magnesium might lessen complications related to vitamin D deficiency which would aid to improve health care services.

\section{Acknowledgment}

Authors would like to express their gratitude to all patients who were included in the study and the laboratory staffs of 151 base hospital.

\section{References}

1. Gessner BD, Plotnik J, Muth PT. 25-Hydroxyvitamin D levels among healthy children in Alaska. The Journal of pediatrics. $2003 \mathrm{Oct}$ 1;143(4):434-437.
2. Ceglia L. Vitamin $D$ and its role in skeletal muscle. Current opinion in clinical nutrition and metabolic care. 2009 Nov;12(6):628.

3. Torun E, Gönüllü E, Özgen IT, Cindemir E, Öktem F. Vitamin d deficiency and insufficiency in obese children and adolescents and its relationship with insulin resistance. International journal of endocrinology. 2013;2013.

4. Ziegler EE, Hollis BW, Nelson SE, Jeter JM. Vitamin D deficiency in breastfed infants in lowa. Pediatrics. 2006 Aug 1;118(2):603-610.

5. Nucci AM, Russell CS, Luo R, Ganji V, Olabopo F, Hopkins B, Holick MF, Rajakumar K. The effectiveness of a short food frequency questionnaire in determining vitamin $\mathrm{D}$ intake in children. Dermatoendocrinology. 2013 Jan 1;5(1):205-210.

6. Misra M, Pacaud D, Petryk A, Collett-Solberg PF, Kappy M. Vitamin $D$ deficiency in children and its management: review of current knowledge and recommendations. Pediatrics. 2008 Aug 1;122(2): 398-417.

7. Bischoff-FerrariHA, GiovannucciE, WillettWC, Dietrich T, Dawson-Hughes B. Estimation of optimal serum concentration of 25 -hdyroxyvitamin $D$ for multiple health outcomes [published correction appears in Am JClin Nutr. 2006;84(5):1253] Am J Clin Nutr. 2006;84(1):18-28.

8. Lips P. Vitamin D physiology. Prog Biophys Mol Biol. 2006;92:4-8.

9. Mithal A, Wahl DA, Bonjour JP, Burckhardt $P$, Dawson-Hughes $B$, Eisman JA, Fuleihan GE, Josse RG, Lips P, Morales-Torres J, IOF Committee of Scientific Advisors (CSA) Nutrition Working Group. Global vitamin D status and determinants of hypovitaminosis D. Osteoporosis international. 2009 Nov 1;20(11):1807-1820.

10. Marcus MB. Vitamin D tests soar as deficiency, diseases linked. USA Today. 2008 Jul 14;13.

11. Kelishadi R, Sharifi-Ghazvini F, Poursafa P, Mehrabian F, Farajian $S$, Yousefy H, Movahedian M, Sharifi-Ghazvini S. Determinants of hypovitaminosis d in pregnant women and their newborns in a sunny region. International journal of endocrinology. 2013;2013.

12. Ardestani PM, Salek M, Keshteli AH, Nejadnik H, Amini M, Hosseini SM, Rafati H, Kelishadi R, Hashemipour M. Vitamin D status of 6-to 7-year-old children living in Isfahan, Iran. Endokrynologia Polska. 2010;61(4):377-382.

13. Zhu Z, Zhan J, Shao J, Chen W, Chen L, Li W, Ji C, Zhao Z. High prevalence of vitamin $D$ deficiency among children aged 1 month to 16 years in Hangzhou, China. BMC public health. 2012 Dec;12(1):126.

14. Harinarayan CV, Ramalakshmi T, Prasad UV, Sudhakar D. Vitamin D status in Andhra Pradesh: a population based study. Indian Journal of Medical Research. 2008 Mar 1;127(3):211.

15. Pramyothin P, Holick MF. Vitamin D supplementation: guidelines and evidence for subclinical deficiency. Current opinion in gastroenterology. 2012 Mar 1;28(2):139-150.

16. Reddy P, Edwards LR. Magnesium Supplementation in Vitamin D Deficiency. Am J Ther. 2017 May 3.

17. Wagner CL, Greer FR. Prevention of rickets and vitamin D deficiency in infants, children, and adolescents. Pediatrics. 2008 Nov 1;122(5):11421152.

18. Garland CF, French CB, Baggerly LL, Heaney RP. Vitamin D supplement doses and serum 25 -hydroxyvitamin $D$ in the range associated with cancer prevention. Anticancer research. 2011 Feb 1;31(2):607-611.

19. Whang R. Magnesium deficiency: pathogenesis, prevalence, and clinical implications. The American journal of medicine. $1987 \mathrm{Mar}$ 20;82(3):24-29.

20. Ardawi MS, Sibiany AM, Bakhsh TM, Qari MH, Maimani AA. High prevalence of vitamin $D$ deficiency among healthy Saudi Arabian men: relationship to bone mineral density, parathyroid hormone, bone turnover markers, and lifestyle factors. Osteoporosis International. 2012 Feb 1;23(2):675-686.

21. Polidoro L, Properzi G, Marampon F, Gravina GL, Festuccia C, Di Cesare E, Scarsella L, Ciccarelli C, Zani BM, Ferri C. Vitamin D protects human endothelial cells from $\mathrm{H} 2 \mathrm{O} 2$ oxidant injury through the Mek/ErkSirt1 axis activation. Journal of cardiovascular translational research. 2013 Apr 1;6(2):221-231.

22. Tylavsky FA, Cheng S, Lyytikäinen A, Viljakainen $H$, Lamberg-Allardt C. Strategies to improve vitamin $D$ status in northern European children: exploring the merits of vitamin D fortification and supplementation. The Journal of nutrition. 2006 Apr 1;136(4):1130-1134. 
23. Schnabel C, Jett K, Friedman JM, Frieling I, Kruse HP, Mautner V. Effect of vitamin D3 treatment on bone density in neurofibromatosis 1 patients: a retrospective clinical study. Joint Bone Spine. 2013 May 1;80(3):315-319.

24. Brehm JM, Celedón JC, Soto-Quiros ME, Avila L, Hunninghake GM, Forno E, Laskey D, Sylvia JS, Hollis BW, Weiss ST, Litonjua AA. Serum vitamin D levels and markers of severity of childhood asthma in Costa Rica. American journal of respiratory and critical care medicine. 2009 May 1;179(9):765-771.

25. Kelishadi R, Salek S, Salek M, Hashemipour M, Movahedian M. Effects of vitamin $D$ supplementation on insulin resistance and cardiometabolic risk factors in children with metabolic syndrome: a triple-masked controlled trial. Jornal de pediatria. 2014 Feb;90(1):28-34.
26. Deng X, Song Y, Manson JE, Signorello LB, Zhang SM, Shrubsole MJ, Ness RM, Seidner DL, Dai Q. Magnesium, vitamin D status and mortality: results from US National Health and Nutrition Examination Survey (NHANES) 2001 to 2006 and NHANES III. BMC medicine. 2013 Dec;11(1):187.

27. Vojtková J, Ciljaková M, Vojarová L, Janíková K, Michnová Z, Sagiová V. Hypovitaminosis D in children with type 1 diabetes mellitus and its influence on biochemical and densitometric parameters. acta Medica (hradec Králové). 2012 May;55(1):18-22.

28. Sahota O, Mundey MK, San P, Godber IM, Hosking DJ. Vitamin D insufficiency and the blunted PTH response in established osteoporosis: the role of magnesium deficiency. Osteoporosis international. $2006 \mathrm{Jul}$ 1;17(7):1013-1021. 